\title{
FAKTOR PENDERITA YANG BERHUBUNGAN DENGAN KESEMBUHAN PENYAKIT TUBERCULOSIS (TBC) PARU DI WILAYAH KERJA DI KECAMATAN NATAR LAMPUNG SELATAN TAHUN 2018
}

\author{
Upik Pebriyani1, Mala Kurniati2, Neno Hasbie 1
}

1Departemen Anatomi, Fakultas Kedokteran, Universitas Malahayati 2Departemen Biologi Kedokteran, Fakultas Kedokteran, Universitas Malahayati 3Departemen Ilmu Kedokteran Komunitas, Fakultas Kedokteran, Universitas Malahayati

\begin{abstract}
Patient Factor Related to Healing Of Tuberculosis (Tb) Lung Disease in Work Area Natar SubDistrict, South of Lampung, 2018. Tuberculosis (TB) still becomes one of the main public health issues in the world even though the efforts of TB eradication has been done in many countries. The highest new case distribution of BTA (+) in South Lampung District in 2017 was in Natar Public Health working area which was as many as 113 cases. One of the efforts that was done to increase the successfulness of pulmonary TB medication is by paying attention to the factors of TB sufferer recovery factor. The objective of this research is to know the factors from the sufferers which are related to pulmonary TB medication recovery on patients who got treatment in Natar SubDistrict working area, South Lampung 2018. Data collection used questionnaires filled during September 2018. There were 66 respondents who met the inclusion and exclusion criteria using non-random sampling. The data was analyzed using univariate, bivariate (Chi-Square) and multivariate (Logistic Regression). Univariate analysis showed various respondents' characteristic and TB medication recovery level of $75.8 \%$. There was relationship between nutrition, medication obedience, other disease complication, knowledge and behavior towards the TB sufferer recovery $(p>0.05)$. Knowledge is the most dominant variable related to the TB sufferer medication recovery.
\end{abstract}

Keywords: TB, recovery, sufferer's factor

\begin{abstract}
Abstrak: Faktor Penderita Yang Berhubungan Dengan Kesembuhan Penyakit Tuberculosis (Tbc) Paru Di Wilayah Kerja di Kecamatan Natar Lampung Selatan Tahun 2018. Tuberculosis (TB) masih merupakan salah satu masalah utama kesehatan masyarakat di dunia walaupun upaya penanggulangan TB telah dilaksanakan di banyak negara. Penyebaran kasus baru BTA (+) di Kabupaten Lampung Selatan pada tahun 2017 yang tertinggi berada di wilayah kerja Puskesmas Natar sebanyak 113 kasus. Upaya yang dilakukan untuk meningkatkan keberhasilan pengobatan TB Paru salah satunya adalah dengan memperhatikan faktor kesembuhan penderita TB. Tujuan penelitian ini mengetahui faktor-faktor penderita yang berhubungan dengan kesembuhan pengobatan TB paru pada pasien yang berobat di Wilayah Kerja Kecamatan Natar, Lampung Selatan Tahun 2018. Pengumpulan data menggunakan kuisioner yang dilakukan selama September 2018. Responden berjumlah 66 yang memenuhi kriteria inklusi dan eksklusi dengan teknik pengambilan non random sampling. Data dianalisis dengan univariat, bivariat (Chi-Square) dan multivariat (Regresi Logistik). Analisis univariat menunjukkan karakteristik responden yang beragam dan tingkat kesembuhan pengobatan TB (75,8\%). Terdapat hubungan antara status gizi, kepatuhan berobat, komplikasi penyakit lain, pengetahuan, dan sikap dengan kesembuhan penderita TB $(p>0,05)$. Pengetahuan merupakan variabel paling dominan terkait dengan kesembuhan pengobatan pada penderita TB.
\end{abstract}

Kata Kunci : TB, kesembuhan, faktor penderita 


\section{PENDAHULUAN}

Tuberkulosis (TB) adalah penyakit menular yang disebabkan oleh Mycobacterium tuberculosis, yang dapat menyerang paru dan organ lainnya (Kementerian Kesehatan RI, 2016). Sampai dengan saat ini TB masih merupakan salah satu masalah utama kesehatan masyarakat di dunia walaupun upaya penanggulangan TB telah dilaksanakan di banyak negara (Muniroh, Aisah and Mifbakhuddin, 2013). Penyakit ini bila tidak diobati atau pengobatannya tidak tuntas dapat menimbulkan komplikasi berbahaya hingga kematian. Tuberkulosis sudah ada di dunia sejak 5000 tahun sebelum masehi, namun kemajuan dalam penemuan dan pengendalian penyakit TB baru terjadi dalam dua abad terakhir (Subuh et al., 2014).

Berdasarkan Global Tuberculosis Report (2015) TB menjadi penyebab utama kematian di seluruh dunia disamping HIV. Pada tahun 2014, TB membunuh 1,5 juta orang terdiri dari 1,1 juta penderita dengan HIV negatif dan dan 0,4 juta penderita dengan HIV positif. Jumlah tersebut terdiri dari 890.000 pria, 480.000 wanita dan 140.000 anak-anak (World Health Organization, 2015).

Berdasarkan hasil Survei Prevalensi TB Indonesia tahun 20132014, diperkirakan prevalensi TB sebanyak 1.600 .000 kasus sedangkan insiden TB sebanyak 1.000 .000 kasus dan mortalitas TB 100.000 kasus. Dengan angka notifikasi kasus tahun 2014 sebanyak 324.000 kasus maka case detection TB di Indonesia hanya sekitar 32 \%. Sebanyak 68\% kasus masih belum diobati atau sudah diobati tetapi belum tercatat oleh program (Dinas Kesehatan Provinsi Lampung, 2016).

Kecamatan Natar merupakan salah satu kecamatan di wilayah Lampung Selatan yang dipilih menjadi lokasi pada penelitian ini. Dipilihnya lokasi ini dikarenakan kecamatan Natar memiliki luas wilayah terbesar diantara kecamatan lainnya di Kabupaten Lampung Selatan yaitu 213 Km2 dengan jumlah penduduk terbesar sejumlah
181.328 jiwa mencakup 26 desa serta penyebaran kasus baru BTA $(+)$ tertinggi ada di wilayah kerja Puskesmas Natar yang merupakan bagian dari kecamatan Natar (Dinas Kesehatan Lampung Selatan, 2018).

Upaya yang dilakukan untuk meningkatkan keberhasilan pengobatan TB salah satunya adalah dengan memperhatikan faktor risiko TB. Menurut Ivanovs (2016) dari penelitian yang telah dilakukan determinasi TB diidentifikasi dan diklasifikasikan berdasarkan faktor risiko penyakit TB. Model determinasi faktor risiko TB ini diadopsi dari Four Layer Model of Health yang dikemukan oleh Dahlgren and Whitehead pada tahun 1991. Tingkat pertama yaitu kondisi sosial ekonomi masyarakat, budaya dan lingkungan. Tingkat kedua yaitu kondisi kehidupan dan kemakmuran. Tingkat ketiga adalah faktor risiko psikososial dan tingkat keempat yaitu faktor risiko yang berhubungan dengan individu (Ivanovs, 2016).

Pada tingkat keempat dari model Four Layer Model of Health yaitu faktor risiko yang berhubungan dengan individu merupakan salah satu faktor penting dalam mempengaruhi kesembuhan penderita TB. Faktor penderita tersebut terdiri dari kebiasaan merokok, penyalahgunaan alkohol, penyalahgunaan obat, dan malnutrisi (status gizi) (Ivanovs, 2016). Selain keempat faktor penderita dari Ivanovs tersebut, Narasimhan et al (2013) menambahkan faktor risiko individu yang berhubungan dengan kesembuhan TB yaitu kondisi imun penderita, usia muda, komplikasi dengan penyakit lain (misalnya pada diabetes), serta pekerja kesehatan (Narasimhan et al., 2013).

tersebut peneliti tertarik untuk melakukan penelitian mengenai faktorfaktor penderita yang berhubungan dengan kesembuhan penyakit Tuberculosis (TB) di Wilayah Kerja Kecamatan Natar Lampung Selatan tahun 2018. Oleh karena itu penelitian ini sangat menarik dilakukan dalam rangka menghasilkan data penelitian 
yang khusus membahas faktor kesembuhan individual penderita.

\section{METODE}

Penelitian ini adalah penelitian analitik observasional dengan pendekatan cross sectional yaitu rancangan studi epidemiologi yang mempelajari hubungan penyakit dan paparan (faktor penelitian) dengan mengamati status paparan dan penyakit serentak pada individu dari populasi tunggal, pada satu saat atau periode. Subjek penelitian adalah penderita tuberkulosis paru berjumlah 66 yang memenuhi kriteria inklusi dan eksklusi berasal dari lima tempat penelitian yaitu Puskesmas Sukadamai, Puskesmas Branti Raya, Puskesmas Natar, Puskesmas Hajimena dan Puskesmas Tanjung Sari. Variabel bebas dalam penelitian yaitu status gizi, kepatuhan berobat, komplikasi dengan penyakit lain, pengetahuan penderita tentang penyakit $\mathrm{TB}$, sikap penderita terhadap kesembuhan TB. Sedangkan variabel terikatnya adalah kesembuhan TB.

Pada penelitian ini alat untuk mengumpulkan data menggunakan kuesioner terstruktur dengan pertanyaan tertutup yaitu pertanyaan yang kemungkinan jawabannya sudah ditentukan terlebih dahulu dan responden tidak diberi kesempatan memberikan jawaban lain. Indikator variabel pada penelitian ini dijadikan sebagai titik tolak untuk menyusun item-item instrumen yang dapat berupa pernyataan atau pernyataan (Poernomo, 2009). Pengolahan data meliputi Editing, Coding, Entry, Cleaning.

Analisis data hasil penelitian disajikan secara univariat untuk menunjukkan karakteristik responden yang beragam dan tingkat kesembuhan pengobatan TB. Analisis bivariat dilakukan analisis tabulasi silang antara variabel bebas dan variabel terikat untuk mencari hubungan antar dua variabel. Proses ini menggunakan uji Chi-Square. Hubungan dinyatakan bermakna bila nilai $\mathrm{p} \leq 0,05$ yang berarti hipotesis diterima dan hubungan dinyatakan tidak bermakna bila nilai $\mathrm{p}>$ 0,05 yang berarti hipotesis ditolak. Analisis multivariat digunakan untuk mengetahui hubungan lebih dari satu variabel independen dengan satu variabel dependen serta untuk mengetahui variabel independen mana yang paling berpengaruh terhadap variabel dependen. Terdapat dua analisis multivariat yang sering digunakan dalam penelitian yaitu analisis regresi logistik dan analisis regresi linear.

\section{HASIL}

\section{Gambaran Karakteristik Responden}

Hasil penelitian diperoleh

karakteristik responden yaitu laki-laki sebanyak 37 orang $(54,4 \%)$ dan perempuan sebanyak 29 orang $(42,6 \%)$. Kelompok umur yang didapat yaitu kelompok umur $15-55$ sebanyak 46 orang $(69,7 \%)$ dan kelompok umur $>55$ sebanyak 20 orang (30,3\%). Distribusi frekuensi strata pendidikan responden didapatkan hasil yaitu SMA/Sederajat sebanyak 15 orang $(22,1 \%)$, SMP/Sederajat sebanyak 16 orang $(23,5 \%)$, SD/Sederajat sebanyak 29 orang $(42,6 \%)$, Tidak Sekolah (TS) sebanyak 6 orang $(8,8 \%)$ sedangkan yang mengenyam pendidikan di Perguruan Tinggi tidak ada.

Distribusi frekuensi karakteristik responden dari pekerjaan yaitu tidak bekerja sebanyak 22 orang $(32,4 \%)$, petani sebanyak 9 orang $(13,2 \%)$, swasta sebanyak 30 orang $(44,1 \%)$, dan wiraswasta sebanyak 5 orang $(7,4 \%)$. Karakteristik responden berdasarkan penghasilan rendah dan tinggi maka diperoleh data yaitu berpenghasilan rendah $\leq 2.168 .702,48$ perbulan sebanyak 61 orang $(89,7 \%)$ dan yang berpenghasilan tinggi $\geq$ 2.168.702, 48 perbulan sebanyak 5 orang $(7,4 \%)$ (tabel 1$)$. 
Tabel 1. Distribusi Frekuensi Berdasarkan Karakteristik Responden di Wilayah Kerja Kecamatan Natar Tahun 2018

\begin{tabular}{|c|c|c|c|c|}
\hline No. & Karakteristik & & Jumlah & Persentase (\%) \\
\hline 1. & $\begin{array}{l}\text { Jenis Kelamin } \\
\text { a. } \\
\text { b. }\end{array}$ & $\begin{array}{l}\text { Laki-laki } \\
\text { Perempuan }\end{array}$ & $\begin{array}{l}37 \\
29\end{array}$ & $\begin{array}{l}54,4 \\
42,6\end{array}$ \\
\hline 2. & $\begin{array}{l}\text { Umur } \\
\text { a. Laki-laki } \\
\text { b. Perempuan }\end{array}$ & & $\begin{array}{l}46 \\
20 \\
\end{array}$ & $\begin{array}{l}69,7 \\
30,3 \\
\end{array}$ \\
\hline 3. & $\begin{array}{l}\text { Pendidikan } \\
\text { a. Akademik/PT } \\
\text { b. SMA/Sederajat } \\
\text { c. SMP/Sederajat } \\
\text { d. SD/Sederajat } \\
\text { e. Tidak Sekolah }\end{array}$ & & $\begin{array}{c}0 \\
15 \\
16 \\
29 \\
6\end{array}$ & $\begin{array}{c}0 \\
22,1 \\
23,5 \\
42,6 \\
8,8\end{array}$ \\
\hline 4. & $\begin{array}{l}\text { Pekerjaan } \\
\text { a. Tidak bekerja } \\
\text { b. Petani } \\
\text { c. Swasta } \\
\text { d. Wiraswasta }\end{array}$ & & $\begin{array}{c}22 \\
9 \\
30 \\
5\end{array}$ & $\begin{array}{c}32,4 \\
13,2 \\
44,1 \\
7,4\end{array}$ \\
\hline 5. & $\begin{array}{l}\text { Penghasilan } \\
\text { a. Rendah } \\
\quad(\leq 2.168 .702,48 \text { perbulan }) \\
\text { b. Tinggi } \\
\quad(\geq 2.168 .702,48 \text { perbulan })\end{array}$ & & $\begin{array}{l}61 \\
5\end{array}$ & $\begin{array}{r}89,7 \\
7,4\end{array}$ \\
\hline
\end{tabular}

Tabel 2. Distribusi Frekuensi Berdasarkan Kesembuhan, Status Gizi, Kepatuhan Berobat, Komplikasi Penyakit lain, Pengetahuan dan Sikap di Wilayah Kerja Kecamatan Natar Tahun 2018

\begin{tabular}{|c|c|c|c|c|}
\hline No. & Variabel & Kategori & Jumlah & $\begin{array}{c}\text { Persentase } \\
(\%)\end{array}$ \\
\hline 1. & Kesembuhan & $\begin{array}{l}\text { Tidak sembuh } \\
\text { Sembuh }\end{array}$ & $\begin{array}{l}9 \\
57\end{array}$ & $\begin{array}{l}13,6 \\
86,4 \\
\end{array}$ \\
\hline 2. & Status Gizi & $\begin{array}{l}\text { Kurang } \\
\text { Normal }\end{array}$ & $\begin{array}{l}21 \\
45 \\
\end{array}$ & $\begin{array}{l}31,8 \\
68,2 \\
\end{array}$ \\
\hline 3. & $\begin{array}{l}\text { Kepatuhan } \\
\text { Berobat }\end{array}$ & $\begin{array}{l}\text { Tidak patuh } \\
\text { Patuh }\end{array}$ & $\begin{array}{l}17 \\
48 \\
\end{array}$ & $\begin{array}{l}25,8 \\
74,2 \\
\end{array}$ \\
\hline 4. & $\begin{array}{l}\text { Komplikasi } \\
\text { Penyakit lain }\end{array}$ & $\begin{array}{l}\text { Ada } \\
\text { Tidak ada }\end{array}$ & $\begin{array}{l}23 \\
43 \\
\end{array}$ & $\begin{array}{l}34,8 \\
65,2\end{array}$ \\
\hline 5. & Pengetahuan & $\begin{array}{l}\text { Tidak baik } \\
\text { Baik }\end{array}$ & $\begin{array}{l}17 \\
49 \\
\end{array}$ & $\begin{array}{l}25,8 \\
74,2 \\
\end{array}$ \\
\hline 6. & Sikap & $\begin{array}{l}\text { Tidak baik } \\
\text { Baik }\end{array}$ & $\begin{array}{l}16 \\
50\end{array}$ & $\begin{array}{l}24,2 \\
75,8\end{array}$ \\
\hline
\end{tabular}


Hasil uji statistik Chi Square antara status gizi dengan kesembuhan dapat disimpulkan bahwa terdapat hubungan antara status gizi dengan kesembuhan TB di 5 puskesmas wilayah kerja Kecamatan Natar Lampung Selatan
Tahun 2018, didapatkan pula $O R=5,6$ dengan $C I$ 1,24-25,25, dimaknai bahwa penderita TB yang mempunyai status gizi kurang memiliki risiko 5,6 kali untuk tidak sembuh dibandingkan penderita TB yang mempunyai status gizi normal.

Tabel 3. Rekapitulasi Analisis data dengan Uji Chi Square Faktor Penderita yang Berhubungan dengan Kesembuhan Penyakit Tuberculosis (TBC) Paru Di Wilayah Kerja Di Kecamatan Natar Lampung Selatan Tahun 2018

\begin{tabular}{llcccl}
\hline \multirow{2}{*}{ No. } & \multirow{2}{*}{ Variabel } & \multicolumn{3}{c}{ Kesembuhan } & \multirow{2}{*}{ Keterangan } \\
\cline { 3 - 5 } & & $\mathbf{p}$ & $\mathbf{O R}$ & $\mathbf{9 5 \%} \mathbf{C I}$ & \\
\hline 1. & Status Gizi & 0,02 & 5,6 & $1,24-25,25$ & Ada hubungan \\
\hline 2. & Kepatuhan Berobat & 0,007 & 8,36 & $1,80-38,78$ & Ada hubungan \\
\hline 3. & $\begin{array}{l}\text { Komplikasi Penyakit } \\
\text { Lain }\end{array}$ & 0,007 & 8,96 & $1,68-47,84$ & Ada hubungan \\
\hline 4. & Pengetahuan & 0,04 & 4,68 & $1,08-20,20$ & Ada hubungan \\
\hline 5. & Sikap & 0,03 & 5,22 & $1,20-22,73$ & Ada hubungan
\end{tabular}

Hasil uji statistik antara kepatuhan berobat dengan kesembuhan didapatkan $p$ value 0,007 ( $p$ value $\leq 0,05$ ) dapat disimpulkan bahwa terdapat hubungan antara kepatuhan berobat dengan kesembuhan TB dan nilai $O R=$ 8,36 dengan $C I$ 1,80-38.78. Hubungan antara komplikasi penyakit lain dengan kesembuhan menunjukkan nilai ( $\mathrm{p}$ : $0,007 ; O R: 8,96 ; C I: 1,68-47,84)$. Hubungan pengetahuan tentang penyakit TB dengan kesembuhan TB menunjukkan hasil yang signifikan dengan nilai ( $p: 0,04 ; O R: 4,68 ; C I$ : $1,08-20,20)$. Hasil statistik antara sikap dengan kesembuhan TB memperlihatkan hasil yang signifikan dengan nilai $(\mathrm{p}: 0,03 ;$ OR : 5,22; $\mathrm{CI}$ : 1,20-22,73) (tabel 3).

\section{PEMBAHASAN}

Status gizi merupakan faktor penting yang mempengaruhi kesembuhan penderita TB dan status gizi dapat menjadi faktor risiko bagi kesembuhan penderita TB, status gizi yang kurang pada penderita meningkatkan risiko sampai 5,6 kali lebih besar daripada penderita dengan status gizi normal. Status gizi dan tuberkulosis (TB) merupakan beban

yang sering dijumpai di negara berkembang. Kedua masalah ini saling berhubungan satu dengan yang lain. Status nutrisi buruk sering ditemukan pada penderita TB aktif dibandingkan individu sehat. Infeksi TB sendiri menimbulkan anoreksia, malabsorpsi nutrien dan mikronutrien serta gangguan metabolisme sehingga terjadi proses penurunan massa otot dan lemak. Suplementasi nutrisi diduga dapat memperbaiki keadaan umum penderita selama pemberian obat antituberkulosis (OAT) tetapi prognosis penderita berkaitan dengan berbagai faktor seperti faktor organisme, individa dan lingkungan (Pratomo et al., 2012).

Salah satu penentu keberhasilan penatalaksanaan terapi tuberkulosis yaitu kepatuhan pasien terhadap terapi. Ketidakpatuhan berobat akan menyebabkan kegagalan dan kekambuhan, sehingga muncul resistensi dan penularan penyakit terus menerus. Hal ini dapat meningkatkan risiko morbiditas, mortalitas dan resistensi obat baik pada pasien maupun pada masyarakat luas. Konsekuensi ketidakpatuhan berobat 
jangka panjang adalah memburuknya kesehatan dan meningkatnya biaya perawatan (WHO Global Tuberculosis Report, 2016). Terkait dengan kepatuhan berobat jalan, dimungkinkan beberapa hal yang mempengaruhinya, dimana faktor tersebut tidak terdapat dalam penelitian ini, seperti peran PMO dan keluarga. Seperti penelitian Muniroh N, dkk tahun 2013 menyatakan pada umumnya kegagalan pengobatan disebabkan oleh karena pengobatan yang terlalu singkat, pengobatan yang tidak teratur dan obat kombinasi yang jelek. Kepatuhan memiliki pengaruh yang besar terhadap kesembuhan. Kepatuhan minum obat di wilayah Puskesmas Mangkang sudah sangat baik, hal ini dikarenakan petugas puskesmas selalu memberikan penyuluhan mengenai keteraturan minum Obat Anti Tuberkulosis (OAT). Hal ini dibuktikan dengan pada penderita sembuh yang patuh minum obat sebanyak $84,2 \%$, sedangkan yang tidak patuh sebanyak $18,2 \%$ (Muniroh et al., 2013).

Ketidakpatuhan untuk berobat secara teratur bagi penderita TB tetap menjadi hambatan untuk mencapai angka kesembuhan yang tinggi. Kebanyakan penderita tidak datang selama fase intensif karena tidak adekuatnya motivasi terhadap kepatuhan berobat dan kebanyakan penderita merasa enak pada akhir fase intensif dan merasa tidak perlu kembali untuk pengobatan selanjutnya (Linda, ZS, \& Tjandra Yoga, 2007). Penelitian yang dilakukan oleh Sari dkk tahun 2016 bertujuan untuk mengetahui hubungan antara pengetahuan, sikap dan kepatuhan berobat jalan pasien TB di 5 RSUD Jakarta. Hasil penelitian menunjukkan bahwa angka kepatuhan berobat sebesar 72,7\% (Ida Diana, Mubasyiroh, \& Supardi, 2016). Penelitian O'Boyle dkk tahun 2002 melaporkan di kota Kinabalu Sabah Malaysia bahwa kepatuhan dapat ditingkatkan dengan peningkatan edukasi penderita, keluarga dan populasi umum, mengurangi biaya transportasi dan lamanya perjalanan (O'Boyle, Power, Ibrahim, \& Watson,
2002). Nuwaha melaporkan di Uganda 92\% penderita menyelesaikan pengobatannya. Hal tersebut disebabkan karena pengobatan penderita pada satu fasilitas kesehatan, baik pada fase intensif maupun fase lanjutan, pengobatan penderita dekat rumah (Nuwaha, 1999).

Salah satu komplikasi penyakit lain pada penderita TB yaitu Diabetes Mellitus (DM). Peningkatan prevalensi DM diikuti dengan peningkatan prevalensi TB. Penderita DM mempunyai risiko 2 hingga 3 kali lebih tinggi untuk mengidap penyakit TB paru dibandingkan penderita tanpa DM dan banyak ditemukan pada usia lebih dari 40 tahun. Penyakit atau infeksi lain yang dapat meningkatkan kejadian TB yaitu HIV. Epidemi Human Immunodeficiency Virus (HIV) berpengaruh pada peningkatan epidemi TB di seluruh dunia yang berakibat pada meningkatnya jumlah penderita TB di tengah masyarakat (Novi, A.A Raka, \& Rini, 2011). Berdasarkan survei yang dilakukan terhadap 875 penderita TB atau mikobateriosis paru di rumah sakit, BP dan puskesmas di Jakarta dan Bandung. Data-data diambil dari tahun 1989 sampai dengan 1999. Hasil survei menunjukkan: adanya DM $(7,2 \%)$, Gastritis (35,1\%), TB-Extra Paru $(16,8 \%)$, PPOM $(3,1 \%)$, Asma Bronkial $(2,5 \%)$, Bronchiektasis $(2,1 \%)$ dan lainlainnya dengan presentasi kecil (Misnadiarly, 1996).

Variabel pengetahuan merupakan faktor risiko kesembuhan penyakit TB. Pengetahuan yang merupakan hasil tahu pada obyek melalui indera yang dimilikinya merupakan faktor dominan dalam hal membentuk perilaku seseorang (Notoatmodjo S., 2010). Hasil penelitian ini tidak sejalan dengan hasil penelitian yang dilakukan oleh Kurniasari dkk tahun 2012 yang bertujuan untuk mengetahui faktor risiko yang mempengaruhi keberhasilan pengobatan TB salah satunya yaitu pengetahuan. Hasil uji statistik didapatkan nilai $\mathrm{p}=0,085$ sementara hasil perhitungan OR didapat hasil $=2,7$ dengan 95\% CI $=0,9-7,3$. Dari pertanyaan yang diajukan menunjukkan 
banyak responden yang belum mengetahui TB menular lewat percikan dahak (89\%), merokok dapat memperbesar kemungkinan TB $(69,2 \%)$, dan tidur terpisah dengan penderita TB merupakan pencegahan penularan TB (72\%) (Kurniasari, Suhartono, \& Cahyo, 2012).

Penelitian ini sejalan dengan yang dilakukan oleh Zubaidah dkk 2013 menunjukkan nilai $\mathrm{OR}=6,750$ yang berarti kesembuhan penyakit TB pada responden dengan pengetahuan kurang 6,750 kali untuk tidak sembuh dibandingkan dengan kesembuhan TB pada responden dengan pengetahuan baik (Zubaidah, Setyaningrum, \& Ani, 2013). Penelitian yang dilakukan oleh Pradnyadewi dan Putra tahun 2013 bahwa 73 orang (89\%) responden memiliki pengetahuan baik sedangkan hanya 9 orang $(11 \%)$ responden memiliki pengetahuan kurang mengenai penyakit tuberkulosis (Pradnyadewi \& Putra, 2013). Rendahnya tingkat pendidikan akan berkorelasi dengan rendahnya sikap responden karena berkaitan dengan rendahnya kemampuan responden dan mempengaruhi kesembuhan TB. Hal ini menyebabkan responden yang kurang memiliki sikap yang baik tentang penyakit TB akan mempengaruhi pola pikir responden yang dimanifestasikan kedalam tindakan untuk melakukan dengan baik, seperti mencegah penularan dengan cara tidak membuang dahak sembarangan. Penelitian Zubaidah dkk tahun 2013 yang menunjukkan data sikap baik responden terhadap kesembuhan penyakit TB sebesar $86,2 \%$ sedangkan sikap yang tidak baik dipresentasekan sebesar 13,8 \% (Zubaidah et al., 2013).

Kurniasari dkk tahun 2012 melaporkan hasil penelitian bahwa sikap responden tentang TB yang kurang banyak terdapat pada responden kelompok kasus $(64,7 \%)$ dibandingkan dengan responden pada kelompok kontrol $(38,2 \%)$ dengan total sikap responden tentang TB yang kurang sebanyak 51,5\%. Hasil uji statistik menunjukkan dimana nilai $\mathrm{p}=0,052$, $\mathrm{OR}=2,9$, dan $95 \% \mathrm{CI}=1,1-7,9$ dan tidak memberikan hasil yang bermakna atau signifikan (Kurniasari, Suhartono, \& Cahyo, 2012). Penelitian Pradnyadewi dan Putra tahun 2013 menyebutkan sebanyak 64 orang (78\%) responden memiliki sikap baik/setuju sedangkan hanya 18 orang $(22 \%)$ responden memiliki sikap kurang/tidak setuju mengenai penyakit tuberkulosis. Sikap responden ditentukan berdasarkan total nilai responden dari jawaban pernyataan-pernyataan yang menjadi indikator (Pradnyadewi \& Putra, 2013).

\section{KESIMPULAN}

Faktor yang terbukti berpengaruh terhadap kesembuhan TBC adalah status gizi, kepatuhan berobat, komplikasi penyakit lain, pengetahuan dan sikap. Diharapkan dapat meningkatkan program kesembuhan TB sesuai dengan hasil penelitian berupa faktor yang berhubungan dengan kesembuhan penderita yaitu status gizi, kepatuhan berobat, komplikasi penyakit lain, pengetahuan dan sikap penderita. Peningkatan pengetahuan responden diharapkan dilakukan kepada penderita TB ataupun masyarakat wilayah kerja Kecamatan Natar untuk aktif mengikuti penyuluhan maupun kegiatan kesehatan lainnya dalam rangka meningkatkan komunikasi, informasi dan edukasi (KIE) mengenai penyakit TB. Tanpa adanya pengetahuan penyakit TB khususnya untuk penderita TB akan lebih sulit mencapai kesembuhan pengobatan TB.

\section{DAFTAR PUSTAKA}

Kementerian Kesehatan RI (2016a) Peraturan Menteri Kesehatan Republik Indonesia Nomor 67 Tahun 2016 tentang Penanggulangan Tuberkulosis. Indonesia. Available at: http://hukor.kemkes.go.id/uploa ds/produk_hukum/PMK_No._67 ttg_Penanggulangan_Tuberkolosi s.pdf.

Muniroh, N., Aisah, S. and Mifbakhuddin, - (2013) 'Faktor- 
Faktor Yang Berhubungan Dengan Kesembuhan Penyakit Tuberculosis (Tbc) Paru Di Wilayah Kerja Puskesmas Mangkang Semarang Barat', Jurnal Keperawatan Komunitas, $1(1)$, pp. 33-42.

Subuh, M. et al. (2014) 'Pedoman Nasional Pengendalian Tuberkulosis', Pedoman Nasional Pengendalian Tuberkulosis, p. 3.

World Health Organization (2015) Global tuberculosis report 2015, WHO Library Cataloguing-inPublication Data. Available at: http://apps.who.int/iris/bitstrea $\mathrm{m} / 10665 / 191102 / 1 / 9789241565$ 059 eng.pdf.

Dinas Kesehatan Provinsi Lampung (2016) 'Profil Kesehatan Provinsi lampung Tahun 2015'. Available at:

https://dinkes.lampungprov.go.id /profil-kesehatan-lampung2015/.

Dinas Kesehatan Lampung Selatan (2018) Profil Dinas Kesehatan Lampung Selatan.

Ivanovs, A. (2016) 'Analysis Of Risk Factors For The Prevalence Summary of the Doctoral Thesis'. Available at: www.rsu.Iv.

Narasimhan, P. et al. (2013) 'Risk factors for tuberculosis.', Pulmonary medicine, 2013, p. $828939 . \quad$ doi: $10.1155 / 2013 / 828939$.

Pratomo, I. P., Burhan, E., \& Tambunan, V. (2012). Malnutrisi dan Tuberkulosis. J Indon Med Assoc, 62(6) Juni 2012), 230-236.

Linda, M., ZS, P., \& Tjandra Yoga, A. (2007). Faktor-Faktor Yang Mempengaruhi Kesembuhan Penderita TB Paru. Retrieved from

http://www.klikpdpi.com/jurnalwarta/jri-07-07/dr.linda.htm

Ida Diana, S., Mubasyiroh, R., \& Supardi, S. (2016). Relationship between Knowledge and Attitude and Patient Compliance Among Outpatient Tuberculosis in
Jakarta Province 2014. Media Litbangkes, 26(4), 243-248.

O'Boyle, S. J., Power, J. J., Ibrahim, M. Y., \& Watson, J. P. (2002). Factors affecting patient compliance with anti-tuberculosis chemotherapy using the directly observed treatment, short-course strategy DOTS). International Journal of Tuberculosis and Lung Disease, 6(4), 307-312.

Nuwaha, F. (1999). High compliance in an ambulatory tuberculosis treatment programme in a rural community of Uganda. Int $\mathrm{J}$ Tuberc Lung Dis 3(1):79-81.

Novi, L., A.A Raka, K., \& Rini, N. (2011). Studi penggunaan obat anti tuberkulosis pada pasien TBHIV/AIDS di RSUP Sanglah Denpasar tahun 2009. Jurnal Manajemen Pelayanan Kesehatan, 14(02), 99-107. Retrieved from https://journal.ugm.ac.id/jmpk/a rticle/viewFile/2594/2325

Misnadiarly. (1996). Survei Penyakit Penyerta pada Penderita TB Paru/Mikobacteiosis Paru secara Retrospektif.

Kurniasari, R. A. S., suhartono, suhartono, \& Cahyo, K. (2012). Faktor Risiko Kejadian Tuberkulosis Paru di Kecamatan Baturetno Kabupaten Wonogiri. Media Kesehatan Masyarakat Indonesia, 11(2), 198-204. Retrieved from http://www.ejournal.undip.ac.id/i ndex.php/mkmi/article/view/539 6

Zubaidah, T., Setyaningrum, R., \& Ani, F. N. (2013). Faktor yang mempengaruhi penurunan angka kesembuhan TB di Kabupaten Banjar tahun 2013. Jurnal Epidemiologi Dan Penyakit Bersumber Binatang, 4(4), 192199.

Pradnyadewi, N. L. N. T. A., \& Putra, I. W. G. A. E. (2013). Gambaran 
Pengetahuan, Sikap, Perilaku Dan

Konversi Penderita Tuberkulosis

Paru Bakteri Tahan Asam (Bta)

Positif Di Kota Denpasar Tahun 2012, 2(2), 1-11. 